\title{
ENVIRONMENTAL MANAGEMENT SYSTEMS AS A DRIVER FOR SUSTAINABILITY: STATE OF IMPLEMENTATION, BENEFITS AND BARRIERS IN GERMAN CONSTRUCTION COMPANIES
}

\author{
Jan-Simon SCHMIDT, Rainard OSEBOLD \\ RWTH Aachen University, Mies-van-der-Rohe-Str. 1, 52074 Aachen, Germany
}

Received 19 Sept 2013; accepted 23 May 2014

\begin{abstract}
The construction industry, as one of almost every economy's major generators of environmental impact, can contribute in large measure to achieving the goals of sustainability. However, most publications in this field deal with sustainability with reference to selecting construction materials and improvements in the operating phase of buildings. When considering ecological sustainability the focus has to be extended from the finished building to the building process. Therefore the actors of the construction sector who are responsible for the production process have to be studied: the construction companies. The goal of this paper is to study the state of ecologically sustainable corporate business management in construction. The state of application of elements of environmental management systems (EMS) is used as an indicator of the current situation in German construction companies. EMS can help continuously to environmentally improve the operating processes of the firms. A broad survey about the extent of EMS has been conducted considering the barriers and drivers. In general, a relatively low interest in EMS and a lack of knowledge is noticeable within the sector. As a result, strategic recommendations are made on how to promote environmental management to foster sustainable thinking in the German construction industry.
\end{abstract}

Keywords: German construction industry, sustainability, environmental management systems, broad survey, strategy.

\section{Introduction}

As in almost every national economy, the German construction sector is one of the economy's major generators of environmental impact, such as emissions and waste. Furthermore, it accounts for an important consumption of natural resources and energy. Estimates indicate that approximately $40 \%$ of the total energy consumed worldwide, $40 \%$ of the waste produced and $40 \%$ of all raw materials consumed are associated with the construction sector (Srdić, Šelih 2011). Thus it is necessary to focus on aspects of ecological sustainability in all phases of building. Besides the key construction project objectives of "cost", "time" and "quality", the environmental objective should be the fourth client objective in construction project management, thereby resulting in a fundamental change within the construction sector (Ofori 1992). The construction companies can contribute to a considerable extent to achieving this goal by implementing aspects of sustainability in their corporate business management (Girmscheid, Selberherr 2012). An environmental management system (EMS) provides methods systematically designed to manage the environmental aspects of production processes. A continuous process of improvement within the EMS ensures that new ideas and innovations are enhanced. The best known and most established standards to implement EMS are the EMAS (Eco-Management and Audit Scheme) and the ISO 14001:2004. Both ISO 14001:2004 and EMAS provide tools to identify and control environmental impacts. Additionally, both systems focus on a continuous improvement process. With these common objectives they are often seen as competitors. However, it is a fact that the ISO 14001:2004 is an integral part of EMAS. Thus the adoption of ISO 14001:2004 as an element of EMAS makes it easier for organizations to obtain an additional EMAS certification without duplicating efforts. Some of the key issues where EMAS goes beyond the ISO 14001:2004 requirements are the legal bases, the required involvement of employees and the defined frequency of required improvements. EMAS requires an evaluation of the environmental performance whilst the ISO 14001:2004 only requires environmental improvements in management (European Commission 2008).

From the late 1990s to the beginning of the new millennium, there was an initial trend in German scientific literature about implementing EMS in construction firms. The number of scientific publications demonstrated the importance of research into EMS-implementation in

Corresponding author: Jan-Simon Schmidt

E-mail: schmidt@ibp.rwth-aachen.de 
construction companies at this time: several dissertations (Rieger 1999; Follmann 1999; Gerstkamp 2000) and scientific anthologies (Blum 1997; Pape et al. 1998) were published. However, it seems as if EMS have not yet been implemented comprehensively in the German construction industry. This hypothesis is based on statistical information discussed in the following section.

\section{Available information on EMS-implementation}

To date (August 2013) only a limited number of German construction companies have implemented EMS. As up-to-date survey results about the extent of EMS are not available, the only possibility of acquiring knowledge specifically about the construction sector is through reviewing existing statistics. The only source of information is the EMAS-registry (Deutscher Industrie- und Handelskammertag 2013). By checking the entries from the economic sector "construction industry", an initial impression about the state of EMS-implementation can be given. According to this, 18 companies in the construction sector were EMAS-certified as of August 2013. As there are 1,224 EMAS-certified companies throughout all German business sectors, construction firms therefore represent only a very small percentage $(1.47 \%)$ of all EMAS-certified companies. The largest share of EMASregistrations can be seen in the manufacturing industry (38\% of EMAS-registrations). The second largest proportion (10\% of EMAS-registrations) represents church organizations and the third largest (6\% of EMAS-registrations) public administrations. The very minor extent of EMS in the German main construction industry becomes clear when the certified firms are set in relation to the total number of 6,727 construction companies (Statistisches Bundesamt 2013). As there are 18 EMAS-certified construction companies, the level of EMAS-implementation amounts to only $0.27 \%$ of all construction companies. As there is not only the EMAS-system as a marker of environmental measures being taken, the question arises as to whether there would be a significantly higher implementation rate if ISO 14001-certified companies were considered as well. According to a survey conducted by Follmann (1999), at the end of the 1990s there were 5 ISO 14001-certified companies out of a sample of 42 largemedium sized and large companies. This would equate to an implementation rate of $11.9 \%$. However, the rate is not representative for the sector as there was a large share of large-scale enterprises in the sample. To date, the state of EMS-implementation is rather unclear. During expert interviews it could be confirmed that the current extent of implementation can be considered to be low.

\section{Research objectives}

The presence of EMS in construction companies indicates the presence of a sustainable corporate business management. The primary objective of this research is to provide a foundation for strategic recommendations to enhance the implementation of EMS and thereby sustain- ability in the German construction sector. In doing so, several specific features of the sector have to be taken into account: a major part $(97.77 \%)$ of this sector is made up of companies classified as Small- or Medium-size Enterprises (SMEs) acting in a local and regional market (Statistisches Bundesamt 2013). About 78\% of the workforce of the German construction industry is employed in SMEs. SMEs are defined by the Commission of the European Communities according to their number of employees and either their annual turnover or balance sheet total. The category of SMEs is made up of enterprises which employ fewer than 250 persons and which have an annual turnover not exceeding 50 million Euros. Furthermore, the annual balance sheet total should not exceed 43 million Euros (Commission of the European Communities 2003). In this present paper a simplified definition for SMEs is used. A classification on the basis of the number of employees is used, as this is considered to be the main criterion according to the Commission Recommendation of 6 May 2003: "The criterion of staff numbers [...] remains undoubtedly one of the most important and must be observed as the main criterion; [...]". In addition, the turnover for the year 2011 was viewed to exclude the possibility of a company being classified incorrectly. For reasons of simplicity, the balance sheet total was not requested in the conducted survey.

Another specific feature of the construction sector is that the production process is influenced by different actors and stakeholders. Construction projects are typically larger and take longer than projects in other sectors and thus involve a large number of actors along the entire value chain of the sector. The connections of planners, contractors, subcontractors and suppliers, all with their various specializations, have to be taken into account. From the point of view of the construction companies the requirements of their clients are most important. The companies of the construction sector are classified into the divisions 41 to 43 of the NACE Classification (NACE Rev. 2 2008). According to this classification, the construction sector includes the construction of buildings (division 41), the construction of civil engineering works (division 42) and specialized construction activities (division 43).

To achieve the primary objective, the survey had four aims: 1) to study the extent of implementation of elements of environmental management in construction companies, thereby including EMS-certified and non-certified firms; 2) to determine the barriers to implementing EMS faced by the companies; 3 ) to investigate the drivers of EMS in the construction sector; 4) to formulate recommendations to strategically enhance EMS-implementation in the sector.

The survey results can be used to acquire a basic knowledge of the implementation rate of EMS and of the benefits and obstacles German construction companies expect if they were to apply such a system. This knowledge can help to formulate recommendations for action 
for decision-makers in politics and economics to foster EMS and thereby green thinking in the construction sector. The study's results provide the following benefits:

1. Enhancing basic knowledge about possible drivers for EMS

2. Identification of the most important barriers to elements of environmental management.

3. The insights gained about the key levers to fostering EMS in the construction industry can help to improve the environmental performance of the construction sector.

Operational details of the application of EMS in construction companies have not been considered in this paper.

\section{Literature review}

As a basis for the development of the questionnaire, a literature review was carried out. The scientific literature analyzed has been classified according to two main sectors: firstly, scientific findings about EMS-implementation in German construction companies, and secondly, international studies on broad surveys about the implementation of EMS in the construction sector. In general, the existing literature was examined in order to get an overview of the current state of knowledge in Germany and the state of implementation in the construction sectors of other countries. Of particular interest were previous findings in other countries relating to the barriers and benefits of EMS-implementation already known.

\subsection{Scientific findings about EMS-implementation in German scientific literature}

The first research works in the field of cleaner construction processing emerged with the increasing ecological awareness in Germany in the 1980s (Olshausen 1983). Research in the context of environmental management was followed up in Germany only as of the mid-1990s. With the adoption of EMAS into national law (Environmental Audit Act) in 1995 (rev. 2002) and the introduction of the ISO 14001:2004 in 1996, the implementation of EMS in the construction sector increasingly became an object of German research. In particular the publications of Blum (1997), Bentlage and Rieger (1998), Follmann (1999), Rieger (1999), Gerstkamp (2000) and Große (2000) can be considered as fundamental works in the field of EMS-implementation in German construction companies. The main findings of previous German research include several difficulties of a broad implementation of EMS in the construction sector. A major obstacle to adopting EMS was found for a large proportion of the construction firms: the SMEs. In general it was found that the monetary and personal efforts for the introduction were considered to be very high. The collection of relevant data was challenging as Electronic Data Processing technology was only used rarely within the sector. Finally it was found that organizational measures could help to implement environmental management standards in construction firms. Through voluntary environmental commitment of the companies, environmental protection is enhanced and thus the compliance with legal and technical requirements can be promoted.

Jancke (2012) developed an approach for German construction firms to consider aspects of sustainability in procuring building materials and subcontractors' services. He conducted three surveys on how German companies deal with sustainability aspects in their procurement procedures at present. The study contains no statements about the implementation rate of EMS in German construction companies in general.

It is noticeable that the scientific interest in these topics has decreased in Germany since the turn of the millennium. After the initial research-trend caused by the establishment of ISO 14001:2004 and EMAS in the mid-1990s it seemed as if there was nothing new left to research. Due to the increased awareness of sustainability among policymakers and the population, research on environmental topics is gaining importance again. Today, about 13 years after the first environmental management trend, it seems as if EMS are not widely established in the German construction industry. Since the mid-1990s, however, the framework conditions have evolved. The standards for EMS-certification have been revised and new legal bases (e.g. European Parliament 2004; TVgG-NRW 2012) have been implemented. Some of the construction companies have established certified EMS and made them an integral part of their organizational processes. In doing so, the certified companies have gained valuable experience regarding the benefits and barriers of EMS. Thus it is of special scientific interest to obtain new insights into the extent of environmental management elements in German construction companies.

\subsection{International broad surveys}

A limited number of broad surveys have been conducted in several countries about the extent of environmental management elements based on a sample of firms. In addition there are various company-based case studies. A literature review by Turk (2009) provides a good summary of previous studies containing publications about broad surveys as well as about case-studies. The review carried out in the present paper only takes into account publications consisting of results about broad surveys based on a sample of firms. The goal of this present research is to conduct a broad survey: therefore publications about case studies in single companies are not considered in this review. The results of previous studies are briefly summarized in chronological order in the following:

A study by Tan et al. (1999) considered the relevance of environmental management to construction companies and in a field study assessed the level of commitment of the construction firms in Singapore. According to the survey results, contractors are aware of the merits of EMS. Systems towards achieving the merits were not instituted. Thus a framework for developing 
and implementing EMS was proposed. To gain knowledge from quality systems for implementing EMS in construction, Ofori et al. (2002) assessed the perceptions and expectations of construction firms in Singapore concerning ISO 9000 certification. The expectations of ISO 14001:2004 certification were also ascertained. Furthermore, the companies' environmental awareness, policies and current practices were studied. The survey-based study found that contractors derive benefits from ISO 9000 but are driven by short-term cost-benefit considerations. Shen and Tam (2002) identified the barriers, benefits and measures for implementing EMS considered by construction companies in Hong Kong. The results of a broad survey indicated that the factors of "contribution to environmental protection", "reduction of environmental risk", "improving environmental image" and "cost saving" were considered the major benefits. Major barriers in Hong Kong included "increasing management cost", "lack of trained staff and expertise", "lack of sub-contractor cooperation", "lack of client support" and "timeconsumption for improving environmental performance". Zeng et al. (2004) analyzed thirty factors affecting the implementation of environmental management in Chinese construction firms by using a structured questionnaire in a broad survey. According to the results the top five factors were "the environmental consciousness of top executives", "environmental consciousness of middle management", "effective implementation of the relevant regulations on environmental management", "the legal system", and "legal enforcement". Abdullah (2005) dealt with the importance of EMS as a tool to mitigate environmental problems in the UK construction industry. The work mentioned that the benefits of an EMS exceed the cost of implementing it. A questionnaire survey investigated the extent of EMS implementation in the UK. The results showed that EMS were not popular amongst professionals who were surveyed. Chen and $\operatorname{Li}$ (2006) found that there was a remarkable disagreement between the registration rate of ISO-certified EMS and the implementation rate of Environmental Impact Assessment (EIA) in the Chinese construction industry. Thus the construction companies in China have not really applied environmental management in construction projects. A questionnaire survey was conducted in order to verify this hypothesis. According to the results, the critical factors for not adopting an EMS are characterized by five classes: governmental regulations, technology conditions, competitive pressures, attitudes to cooperation, and cost-benefit efficiency. Šelih (2007) discusses the barriers and benefits associated with ISO 14001-certificated EMS in construction companies in Slovenia. The results of a broad survey were presented and analyzed. The majority of the construction firms that responded had implemented a Quality Management System (QMS) and about half of the respondents had also established an EMS. The correlation between the state of implementation and the size of the companies was investigated. As a result it was observed that fewer SMEs were using an EMS than larger companies: SMEs tend to see the required documentation as a major obstacle towards EMS implementation. Turk (2009) particularly investigated the benefits associated with ISO 14001:2004 certification in Turkish construction firms. A structured questionnaire survey was used to investigate whether there was a dependence or relation between the characteristics of the answering firms and having an ISO 14001:2004 certification. In addition, the differences in the perceptions relating to ISO 14001:2004 certification were studied by taking into consideration both the firms' characteristics and the different groups of certified and non-certified companies. As a result there is a relation between the companies' characteristics and having implemented an ISO 14001:2004 certification. Sakr et al. (2010) reported on the results of their research on the environmental awareness of the top 50 Egyptian construction firms. The EMS-awareness and opinions about the companies' responsibility towards the environment was investigated. The barriers as well as the drivers for ISO 14001:2004 adoption were assessed by the responding companies. The survey results indicated that there was a lack of information among the top contractors in Egypt due to the absence of local institutions promoting the introduction of EMS. They found a correlation between the awareness of ISO 14001:2004 and the presence of ISO 9000 certification. All of the major obstacles selected by non-ISO 14001-certified contractors related to a lack of knowledge about the benefits of EMS.

It is apparent that the results of the broad surveys vary widely from country to country. Thus the extent of implementation and the barriers and drivers, cannot be concluded from the previous findings from other countries. A comparison between the different results of surveys from diverse countries could be a topic for further study. However, the beneficial factors (BFs) and environmental management barriers (EBs) already identified can be adopted from the existing publications such as that of Shen and Tam (2002). The EBs and BFs assessed in the survey are presented in Table 1.

\subsection{Research hypotheses}

Based on the findings of the literature review and expert interviews hypotheses were set up:

- Hypothesis 1: There is a correlation between the size category of the construction companies (SME or major enterprise) and having a certified EMS.

- Hypothesis 2: There is a lack of knowledge about EMS in the construction companies and a lack of confidence in the certification systems.

- Hypothesis 3: The main barriers and drivers for EMS-implementation are considered differently by certified and non-certified companies.

- Hypothesis 4: The main barriers and drivers for EMS-implementation are considered differently by SMEs and major enterprises.

- Hypothesis 5: German construction companies have 
Table 1. Beneficial factors (BFs) and environmental management barriers (EBs)

\begin{tabular}{|c|c|}
\hline Abbreviation & Environmental management barriers (EB) \\
\hline EB 1 & $\begin{array}{l}\text { No competitor starts introducing ISO 14001/ } \\
\text { EMAS first }\end{array}$ \\
\hline EB 2 & $\begin{array}{l}\text { Complicated documentation process/ Increase } \\
\text { in documentation workload }\end{array}$ \\
\hline EB 3 & EMS standards are unsuitable for construction \\
\hline EB 4 & Increase in management and operational costs \\
\hline EB 5 & $\begin{array}{l}\text { Difficult coordination of environmental } \\
\text { performance with subcontractors }\end{array}$ \\
\hline EB 6 & Lack of trained staff and expertise \\
\hline EB 7 & Lack of consultants helping to introduce EMS \\
\hline EB 8 & $\begin{array}{l}\text { Lack of supplier and subcontractor } \\
\text { cooperation }\end{array}$ \\
\hline EB 9 & Lack of governmental pressure \\
\hline EB 10 & $\begin{array}{l}\text { Lack of environmentally sound materials and } \\
\text { technologies }\end{array}$ \\
\hline EB 11 & Lack of engagement of management \\
\hline EB 12 & $\begin{array}{l}\text { Change of existing practice of company } \\
\text { structure and policy }\end{array}$ \\
\hline EB 13 & $\begin{array}{l}\text { Lack of knowledge about EMAS and ISO } \\
14001 \text { in construction business }\end{array}$ \\
\hline EB 14 & $\begin{array}{l}\text { Lack of working staff support/ Lack of } \\
\text { worker support }\end{array}$ \\
\hline Abbreviation & Beneficial factors (BF) \\
\hline BF 1 & $\begin{array}{l}\text { Cost saving due to reduction of contributions } \\
\text { for insurance }\end{array}$ \\
\hline BF 2 & Increased productivity by improved processes \\
\hline BF 3 & Increased overall business competitiveness \\
\hline BF 4 & Lower operating costs and increased profit \\
\hline BF 5 & Improved cooperation with authorities \\
\hline BF 6 & $\begin{array}{l}\text { Reduction, reuse and recycling of construction } \\
\text { and demolition wastes }\end{array}$ \\
\hline BF 7 & Improvement of quality \\
\hline BF 8 & $\begin{array}{l}\text { Continuous improvement of corporate } \\
\text { environmental protection }\end{array}$ \\
\hline BF 9 & Improvement of safety and health protection \\
\hline BF 10 & Solving environmental issues and problems \\
\hline BF 11 & Legal certainty \\
\hline BF 12 & Improving corporate environmental image \\
\hline
\end{tabular}

not implemented environmental aspects comprehensively in their procurement of subcontractors and supplies.

- Hypothesis 6: It is easier for construction companies to establish an EMS if a QMS is already in place.

To verify the above-mentioned hypotheses the data were evaluated inductively using the IBM SPSS 19 statistics software. Based on probability calculations, inductive statistics aim to draw conclusions from the sampled companies and extend the findings to the population of all companies of the sector. These conclusions are based on hypothesis testing. In the statistical test procedure p-values are generated to determine the significance of the results as an indicator of whether a correlation exists between the selected variables. If there is strong evidence against the null hypothesis, it is rejected and an alternative hypothesis has to be anticipated. Table 2 specifies the p-values and the related significance levels (Bühl 2012).

Table 2. p-values and the related significance levels

\begin{tabular}{cc|l}
\hline \multicolumn{2}{c|}{ Significance Level } & \multicolumn{1}{c}{ Specification } \\
\hline $\mathrm{p}>0.05$ & not significant \\
\hline $\mathrm{p} \leq 0.05$ & $(5 \%)$ & significant \\
\hline $\mathrm{p} \leq 0.01$ & $(1 \%)$ & very significant \\
\hline $\mathrm{p} \leq 0.001$ & $(0.1 \%)$ & highly significant \\
\hline \multicolumn{2}{r}{}
\end{tabular}

The statistical dependence between two ordinally scaled variables is measured using the Spearman correlation coefficient. This coefficient is a measure of statistical dependence between the two tested variables using a monotonic function (Schendera 2004). In addition to the strength of the Spearman correlation, a small p-value $(<=0.05)$ is crucial for a correlation between the tested variables. Table 3 shows the interpretation of the correlation coefficient (Raithel 2008).

Table 3. Interpretation of the correlation coefficient

\begin{tabular}{c|l}
\hline $\begin{array}{c}\text { Correlation Coefficient } \\
\text { (absolute value) }\end{array}$ & \multicolumn{1}{c}{ Interpretation } \\
\hline up to $|0.2|$ & very low correlation \\
\hline up to $|0.5|$ & low correlation \\
\hline up to $|0.7|$ & moderate correlation \\
\hline up to $|0.9|$ & high correlation \\
\hline above $|0.9|$ & very high correlation \\
\hline
\end{tabular}

\section{Methodology}

\subsection{Development of the questionnaire}

The online-based questionnaire was created based on the findings of the literature review and expert interviews. For the development of the questionnaire and for the survey itself the software "Unipark -EFS survey" was employed. After completion of a first pre-test-version of the questionnaire, a pilot survey was conducted for fine-tuning. Five companies were invited to complete the pre-test. Several questions were revised in accordance with their feedback. Furthermore, the average processing time of the pre-testers was determined to ensure that it would not take too long to complete the questionnaire. Afterwards the final questionnaire was created, containing five main sections: 1) the company's profile and information about the participant in person; 2) elements of environmental management on a company level; 3 ) the drivers and barriers for implementing certified EMS; 4) "Green aspects" in the procurement of subcontractors' services and supplies; and 5) the connection between EMS and quality management systems (QMS).

To be able directly to address the different levels of experience of the participants, filter questions were inserted into the questionnaire. This means that according to e.g. the presence of a certified EMS in a respondent's 
company, the further course of the questionnaire was different to that of the respondents from non-certified companies. Thus, the certified companies were asked about the benefits and barriers they had experienced, while the non-certified companies were asked about the benefits and barriers they would expect if they were to adopt an EMS.

\subsection{Conducting the survey}

The survey was launched at the beginning of March 2013 and was carried out over a period of 4 months. The sample frame included 200 randomly chosen construction companies. The only criterion for choosing the firms was the presence of a company homepage providing a contact phone number. In the first step, the firms were contacted by phone to find a suitable contact person, preferably from the executive board or senior personnel in management functions in central departments or in construction management. Afterwards a personal invitation for the online-based survey was sent by email. Those invited were informed that the survey would be carried out on an entirely anonymous basis. The non-responding firms were reminded by email one week after the initial invitation to the survey. One week before the survey was closed, a second and last reminder was sent to the remaining nonresponding contact persons. After terminating the survey 49 complete questionnaire replies had been received. A quantity of 49 completed data sets is appropriate for compiling a meaningful statistic according to Hauser (1979).

The mean processing time for answering the questionnaire, designed to keep reasonable time expenditure for the participants, was 16 minutes.

\section{Survey results}

\subsection{Profile of participants}

According to the survey, $51 \%(25)$ of the completed questionnaires were answered by the general manager, $20.4 \%$ (10) by department managers, $10.2 \%$ (5) by construction managers, $10.2 \%$ (5) by quality representatives and $8.2 \%$ (4) by other senior personnel. All the respondents were professionals.

All of the contractors operate in the German market and $24.5 \%$ (12) of the firms additionally operate in other European countries. Only 8.2\% (4) also operate in non-European countries. A major part of 14 German federal States were represented among the participating companies' headquarters. Most of the responding companies are located in North Rhine-Westphalia, RhinelandPalatinate and Baden-Wuerttemberg. According to the statistical classification of economic activities in the European Community (NACE Rev. 2 2008), 44.9\% (22) of the firms operate in the field of Construction of Buildings, $79.6 \%$ (39) in Civil Engineering and 8.2\% (4) in Specialized Construction Activities.

The companies of the sample had to be classified according to their size according to the Commission of the European Communities (2003). A simplified classi- fication according to the criterion of the number of employees is used in this section as this criterion is the most meaningful indicator (see Section 2). In 32.7\% (16) of the companies surveyed, more than 250 employees were employed. That means that according to the total number of employees, $67.3 \%$ (33) of the participating firms were classified as SMEs.

The classification of the responding companies is presented in Table 4.

Table 4. Classification of the responding companies

\begin{tabular}{l|ll|ll}
\cline { 2 - 5 } & \multicolumn{1}{l}{ turnover } & \multicolumn{3}{|c}{ employees } \\
\hline $\begin{array}{l}\text { microenterprise } \\
\begin{array}{l}\text { small } \\
\text { enterprise }\end{array}\end{array}$ & $\leq 2$ Mio. $€$ & $10.2 \%$ (5) & $<10$ & $2 \%(1)$ \\
$\begin{array}{l}\text { medium-sized } \\
\text { enterprise }\end{array}$ & $\leq 50$ Mio. $€$ & $38.8 \%(19)$ & $<250$ & $42.9 \%(21)$ \\
$\begin{array}{l}\text { large scale } \\
\text { enterprise }\end{array}$ & $>50$ Mio. $€$ & $26.5 \%(13)$ & $>250$ & $32.7 \%(16)$ \\
\hline
\end{tabular}

\subsection{Extent of EMS implementation}

The results of the survey indicate that $42.9 \%$ (21) of the companies have implemented an environmental policy. Only those participants with an environmental policy were asked further questions about the implementation of EMS-elements in their company.

Nearly one third $(30.6 \%, 15)$ of the total number of respondents indicated that they had implemented a noncertified EMS. 4 of these companies are planning to get a certification within the next 5 years. About $14.3 \%$ (7) had a certificate according to ISO 14001:2004. All of the ISO 14001:2004 certified firms had a certified QMS in accordance to ISO 9001. Only 2 companies had an additional EMAS-certification. This is because the effort to obtain an EMAS-certificate is greater than the effort for an ISO 14001:2004 certification. Altogether there were 9 certified responding companies. 4 of them had only had certification of EMS for less than 4 years. Only 2 companies had been certificated since 2001. It seems as if EMS-certifications are relatively new in the construction sector even though the certification schemes have existed since the mid-1990s. Only 4 of the certified companies employed a non-certified EMS for between 3 to 5 years before the certification. One third $(33.3 \%, 3)$ of the certified companies were large-scale enterprises with a total turnover of more than 50 million euros and had more than 500 employees. The other two thirds (66.6\%, 6 ) were larger medium-sized companies. For the correlation analysis two size categories are created as described in Section 2: the SMEs (33 companies) and the largescale enterprises (16 companies).

Among the 33 SMEs, there are 4 companies with a certified EMS. This corresponds to a share of $12 \%$. The size category of the 16 large-scale enterprises contains 5 certified companies representing $31 \%$ of this size category. The correlation is low (Spearman correlation $=0.328$ ). The $\mathrm{p}$-value is lower than $\mathrm{p}=0.05$. Thus a significant 
positive correlation could be confirmed between the presence of certified EMS and company's size category. As a result, hypothesis 1 is not rejected.

The question of whether certified EMS according to ISO 14001:2004 or EMAS are generally suitable for construction firms was answered with "No" by $24.5 \%$ (12) of the total respondents number. There were $59.1 \%$ (28) of the participants with no opinion. Only $16.3 \%$ (8) of the participants thought that the certification schemes were suitable for the construction sector. The question was answered differently depending on whether the firms were certified or not. 7 of the 9 certified companies confirmed that ISO 14001:2004 and EMAS suited the requirements of construction firms. Only one of the noncertified companies affirmed this. 11 of the non-certified firms answered with "No, certified EMS according to ISO 14001:2004 or EMAS are generally not suitable for construction firms". Thus it can be surmised that the noncertified companies are not sufficiently informed about the possibilities of certified EMS. Another fundamental barrier is the basic attitude of $28.2 \%$ of the non-certified companies that the certification schemes do not suit the specific requirements of construction firms.

Hypothesis 2 was given a more definite form by formulating hypothesis 2A: "Non-certified companies consider certified EMS to be generally not suitable for construction firms." The relatively high Spearman correlation coefficient $(0.792)$ shows a significant correlation between the assessment of the suitability of EMS in construction companies and the presence of a certified EMS. The significance level amounts to $\mathrm{p}=0.000$ (=highly significant). The hypothesis $2 \mathrm{~A}$ is not rejected.

The survey's results confirm hypothesis 2 on the lack of confidence in the certification schemes. The high share of companies that had no opinion shows a generally low state of knowledge about the applicability of certified EMS in the sector.

\subsection{Barriers and drivers for EMS implementation}

\subsubsection{Barriers experienced by certified companies}

The 9 certified companies were asked to assess possible barriers that can occur during the implementation of an EMS. The list of barriers was developed on the basis of the literature review (see Table 1). The different barriers had to be graded by the participants on a scale from 1 (no barrier at all) to 4 (strong barrier). The participants were given the opportunity to select "no response" if they had no opinion about any of the given barriers. An average grade was calculated from the grades given by the 9 certified responding companies. The results are presented in Table 5.

The results show that the 4 major barriers to EMS implementation experienced by certified companies were firstly "EB 13 - lack of knowledge about EMAS and ISO 14001:2004 in the construction business", joint-secondly "EB 6 - Lack of trained staff and expertise" and "EB
Table 5. Barriers experienced by certified and expected by non-certified companies

\begin{tabular}{c|c|c|c|c}
\hline Abbreviation & \multicolumn{2}{c}{ certified } & \multicolumn{2}{c}{ non-certified } \\
\hline & aver. grade & rank & aver. grade & rank \\
\hline EB 1 & 1.33 & 9 & 2.71 & 7 \\
\hline EB 2 & 2.29 & 5 & $\mathbf{3 . 4 1}$ & $\mathbf{2}$ \\
\hline EB 3 & 1.50 & 8 & 2.56 & 7 \\
\hline EB 4 & $\mathbf{2 . 6 3}$ & $\mathbf{2}$ & $\mathbf{3 . 5 0}$ & $\mathbf{1}$ \\
\hline EB 5 & 2.29 & 5 & 3.09 & 4 \\
\hline EB 6 & $\mathbf{2 . 6 3}$ & $\mathbf{2}$ & $\mathbf{3 . 2 7}$ & $\mathbf{3}$ \\
\hline EB 7 & 1.80 & 7 & 2.42 & 8 \\
\hline EB 8 & 2.00 & 6 & 2.39 & 9 \\
\hline EB 9 & $\mathbf{2 . 5 0}$ & $\mathbf{3}$ & 2.82 & 6 \\
\hline EB 10 & 2.00 & 6 & 2.30 & 12 \\
\hline EB 11 & 2.43 & 4 & 2.29 & 13 \\
\hline EB 12 & 2.29 & 5 & 2.36 & 10 \\
\hline EB 13 & $\mathbf{3 . 0 0}$ & $\mathbf{1}$ & 2.97 & 5 \\
\hline EB 14 & 2.29 & 5 & 2.32 & 11 \\
\hline & & & &
\end{tabular}

4 - Increase in management and operational costs" respectively, and thirdly "EB 9 - Lack of governmental pressure". Two major obstacles are hence connected with the currently low knowledge base with regard to EMS. Thus, a sector-specific set of guidelines on the subject of EMS for the construction sector is needed which helps to overcome these obstacles, as proposed by Hiete et al. (2011). Such guidelines, developed on the basis of current best practice, need to be widely communicated. Existing documents from the 1990s and early 2000s have become dated. Even though a major share of the certified companies in the sample was large-sized and larger mediumsized, another major barrier was the increase in management and operational costs. However, it seems as if there are no differences regarding the EMS-barriers with regard to the size category of the companies in the sample (see Section 5.5).

\subsubsection{Barriers expected by non-certified companies}

The majority of the responding companies had not implemented an EMS. These companies were asked which barriers to implementing EMS they would expect. They had to assess the same barriers as the certified companies, graded on the same scale. The average grades are presented in Table 5. The 3 major barriers for the non-certified companies were: firstly "EB 4 - Increase in management and operational costs", secondly "EB 2 - complicated documentation process" and thirdly "EB 6 - lack of trained staff and expertise". As a result, 2 of the major obstacles for non-certified companies are connected with resource use in terms of money/human resources and efforts for the documentation process.

Figure 1 compares the average grading of the environmental management barriers of the certified and noncertified companies. In general, the barriers were rated higher by the non-certified companies. 


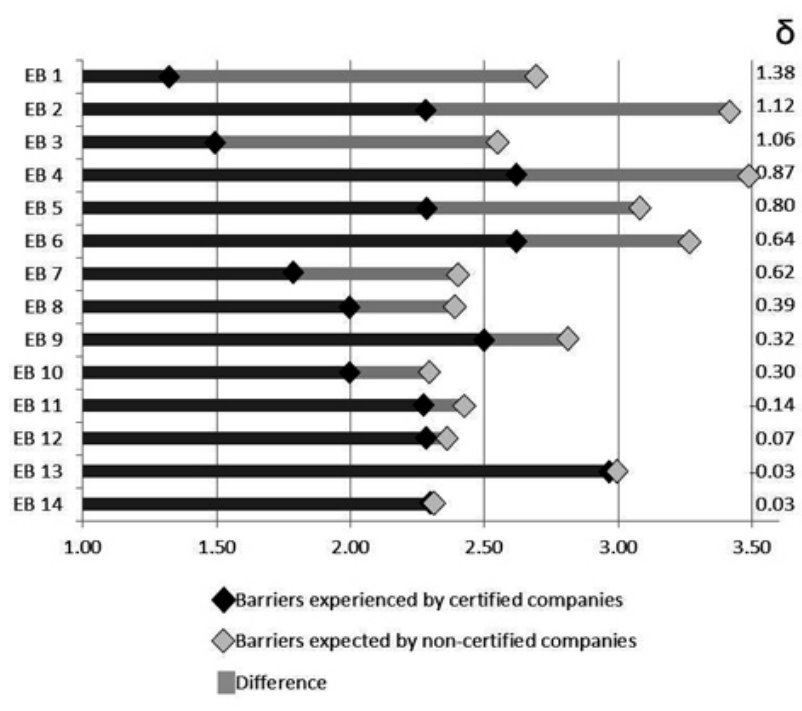

Fig. 1. Barriers experienced by certified and expected by noncertified companies

\subsubsection{Benefits experienced by certified companies}

To evaluate possible drivers for EMS, the benefits experienced had to be assessed by the 9 certified companies. A list of benefits (see Table 1), developed on the basis of the literature review, had to be graded on a scale from 1 ("no benefit at all") to 4 ("strong benefit"). The most important benefit for the certified companies was the "BF 8 - Continuous improvement of corporate environmental protection". Secondly, "BF 9 - Improvement of safety and health protection" was graded as a major benefit. The third most beneficial factor was "BF 11 - Legal certainty". The grades assessed for all of the beneficial factors are presented in Table 6.

Table 6 . Benefits experienced by certified and expected by non-certified companies

\begin{tabular}{c|c|c|c|c}
\hline Abbreviation & \multicolumn{2}{c}{ certified } & \multicolumn{2}{c}{ non-certified } \\
\hline & aver. grade & rank & aver. grade & rank \\
\hline BF 1 & 1.33 & 9 & 2.82 & 8 \\
\hline BF 2 & 1.89 & 8 & 3.14 & $\mathbf{2}$ \\
\hline BF 3 & 1.89 & 8 & 3.11 & $\mathbf{3}$ \\
\hline BF 4 & 1.89 & 8 & 2.94 & 6 \\
\hline BF 5 & 2.11 & 7 & 3.00 & 5 \\
\hline BF 6 & 2.33 & 6 & 3.00 & 5 \\
\hline BF 7 & 2.67 & 4 & 3.14 & 2 \\
\hline BF 8 & 3.22 & $\mathbf{1}$ & 2.76 & 10 \\
\hline BF 9 & 3.00 & $\mathbf{2}$ & 3.38 & $\mathbf{1}$ \\
\hline BF 10 & 2.56 & 5 & 2.89 & 7 \\
\hline BF 11 & 2.75 & $\mathbf{3}$ & 3.08 & 4 \\
\hline BF 12 & 2.33 & 6 & 2.50 & 11 \\
\hline
\end{tabular}

In any case, the benefits seem to outweigh any disadvantages. All of the 9 certified participating companies will continue active practicing of their EMS in the future. These experiences by certified companies have to be communicated to create incentives for the sector to implement EMS extensively. Additional details were asked about benefits in the tender process. Only 4 of the respondents stated that they already had had an advantage due to their certified EMS in the tender process for public projects. One participant stated an advantage in private tenders. It is therefore indicated that environmental regulation instruments can improve the competitive performance of construction firms, as has already been ascertained by Testa et al. (2011). However, 4 of the respondents did not claim to have experienced advantages during their tender processes.

\subsubsection{Benefits expected by non-certified companies}

The non-certified companies were asked to assess the same possible drivers as the certified companies. However, they were asked to assess these beneficial factors by answering two questions: the first read "To what extent would you/your company be motivated by the following beneficial factors to implement a certificated EMS?" The different beneficial factors were rated on a scale from 1 ("not motivated at all") to 4 ("strongly motivated"). In the second question the respondents were asked to assess how realistically they considered these factors could be reached and were likely to lead to an advantage (attainability of the beneficial factors). The evaluation was carried out on a scale from 1 ("cannot realistically be reached") to 4 ("can be reached very realistically").

According to the replies received, the following "top three drivers" were identified: the factor "BF 9 Improvement of safety and health protection" is the most important driver for non-certified companies. "BF 7 - Improvement of quality" is the second most important and "BF 3 - Increasing overall business competitiveness" the third most important factor. Comparing these results with the benefits experienced by certified companies, there is one similar driver (BF 9 - Improvement of safety and health protection) in the "top three drivers" for both certified and non-certified companies. It seems as if this driver could help to foster EMS in the construction sector as it would motivate non-certified companies to implement EMS and could already be reached by the certified companies. However, the improvement of safety and health protection is not the core objective of an EMS.

The differences between the assessed grades for $\mathrm{BF}$ of the certified and non-certified companies are shown in Figure 2. In general, the certified companies considered the beneficial factors to be lower than the non-certified companies did. The largest difference can be found in the assessment of the "BF 1 - Cost saving due to the reduction of contributions for insurance". In addition, the certified companies similarly considered the possibility of increasing their productivity by improving their processes with an EMS as lower than the non-certified companies did. The order of the beneficial factors has been specified according to the difference between the assessments of certified and non-certified companies. Further differences can be read in Figure 2 . 


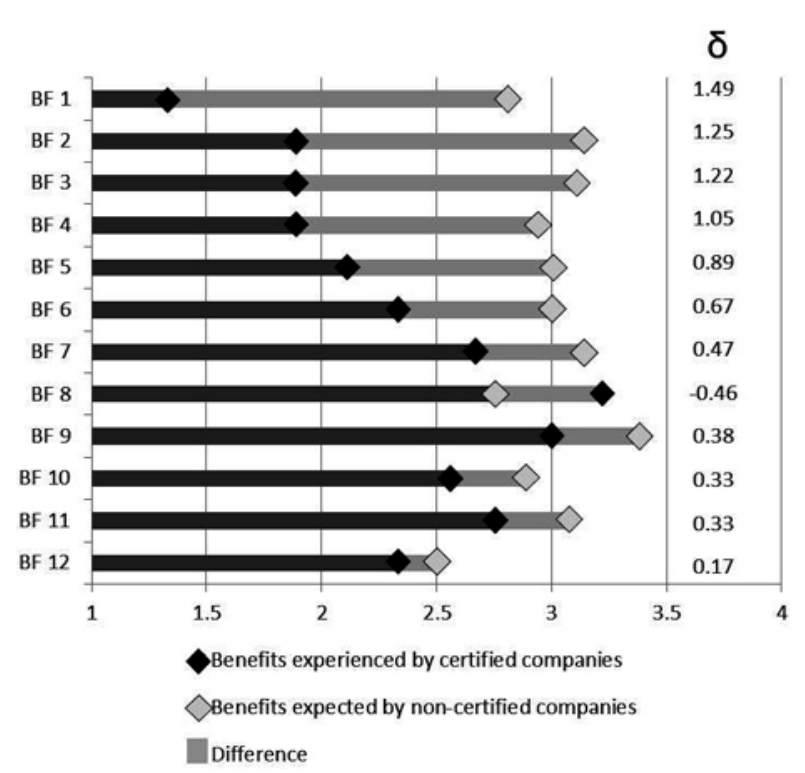

Fig. 2. Benefits experienced by certified and expected by non-certified companies

Regarding the attainability of the beneficial factors, the result is that in general the companies did not expect the beneficial factors could be reached to a great extent. The differences between the average grades of the assessed beneficial factors and the expected attainability are presented in Figure 3. The major differences occur in the factors of "BF 2 - Increasing productivity by improved processes", "BF 4 - Lower operation cost and increased profit" and "BF 7 Increasing Quality". Thus it is possible to conclude that beneficial factors for implementing EMS exist, but the non-certified companies expected only a limited attainability of these factors. The non-certified companies in particular did not expect that they could increase productivity and lower operation cost.

The previous sections have shown that there are significant differences between the assessments of certified and non-certified companies. Hypothesis 3 is not rejected.

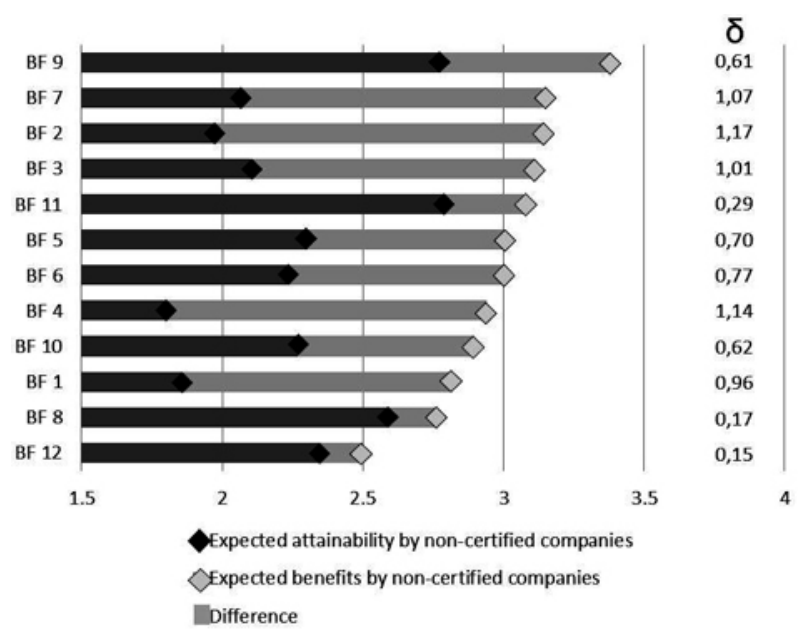

Fig. 3. The differences between the average grades of the assessed beneficial factors and the expected attainability

\subsection{Differences between SMEs and large-scale enterprises in the assessments}

According to hypothesis 4 a difference between SMEs and large-scale enterprises in their assessment of the beneficial factors is expected. However, according to the analyzed survey data there are only slight differences in the assessments. Large-scale enterprises evaluate "BF 11 Legal certainty" as the most important factor. SMEs assess the factor "BF 9 - Improvement of safety and health protection" as most important. "BF 11 - Legal certainty" comes, in the assessment of the SMEs, in the last third of this ranking. "BF 2 - Increasing productivity by improved processes" and "BF 7 - Increasing Quality" are the second and third most important beneficial factors for SMEs. Table 7 shows the ranking of the top beneficial factors of the SMEs in comparison with the large-scale enterprises.

Table 7. Ranking of the top 5 beneficial factors of the SMEs in comparison with the major enterprises

\begin{tabular}{|c|c|c|c|}
\hline $\begin{array}{l}\text { Abbre- } \\
\text { viation }\end{array}$ & Beneficial Factors & SMEs & $\begin{array}{l}\text { Large scale } \\
\text { Enterprises }\end{array}$ \\
\hline BF 9 & $\begin{array}{l}\text { Improvement of safety and } \\
\text { health protection }\end{array}$ & 1 & 2 \\
\hline BF 2 & $\begin{array}{l}\text { Increased productivity by } \\
\text { improved processes }\end{array}$ & 2 & 3 \\
\hline BF 7 & Improvement of quality & 3 & 5 \\
\hline BF 3 & $\begin{array}{l}\text { Increased overall business } \\
\text { competitiveness }\end{array}$ & 4 & 4 \\
\hline BF 4 & $\begin{array}{l}\text { Lower operating costs and } \\
\text { increased profit }\end{array}$ & 5 & (..) \\
\hline BF 6 & $\begin{array}{l}\text { Reduction, reuse and } \\
\text { recycling of construction } \\
\text { and demolition wastes }\end{array}$ & 5 & (..) \\
\hline BF 11 & Legal certainty & $(.)$. & 1 \\
\hline BF 5 & $\begin{array}{l}\text { Improved cooperation with } \\
\text { authorities }\end{array}$ & $(.)$. & 5 \\
\hline
\end{tabular}

Contrary to hypothesis 4 , there are no differences between the size categories of SMEs and large-scale enterprises when assessing the top 5 obstacles for implementing EMS. Both company size categories rate "EB 4 - Increase in management and operational costs", "EB 2 - Complicated documentation process", "EB 6 Lack of trained staff and expertise", "EB 5 - Difficult coordination of environmental performance with subcontractors" and "EB 9- Lack of governmental pressure" as the top 5 barriers to EMS implementation.

As a result, hypothesis 4 can only partly be confirmed. There are slight differences in the ranking of the beneficial factors but no differences regarding the barriers. It can be seen that SMEs will be particularly motivated to implement EMS if the productivity, the quality and safety, and health protection can be improved. 


\section{5. "Green aspects" in the procurement of subcontractors' services and supplies}

In the survey, 41 of the responding firms were awarding contracts to sub-contractors. About two thirds (14) of them answered that they generally ensure environmentally sound tendering. However, only 4 of these firms had a guideline or handbook for an environmentally friendly preparation of tender documents. The clear majority of $29(70.7 \%)$ of the tendering companies never required a certified EMS from the sub-contractors. The remaining participants did so "only rarely" (8) or required EMS "occasionally" (4). For 38 companies $(92.7 \%)$ a certified EMS was not important for the selection of suppliers. In conclusion, EMS are of secondary importance in the procurement of subcontractors' services and supplies. Hypothesis 5, that German construction companies have not implemented environmental aspects comprehensively in their procurement of subcontractors and supplies, is confirmed. This result also confirms the findings of Jancke (2012).

\subsection{The connection between EMS and QMS}

According to the scientific literature (e.g. Ofori et al. 2002) it is significantly easier to implement an EMS if the company has already implemented a QMS. 22 of the firms surveyed have a certified QMS in accordance with ISO 9001. All of the firms with a certified EMS first implemented a certified QMS. This can be explained by the fact that the ISO 9001 has existed since 1987 and the ISO 14001:2004 or EMAS were established in the mid-1990s. 10 of the ISO 9001 certified firms have established their certified QMS since the 1990s. 7 (77.7\%) of the firms with a certified EMS indicated that the ISO 14001:2004 implementation was easier as they already had ISO 9001. From this it follows that hypothesis 6 is not rejected.

The question of whether the statement "in several years the certificates in accordance to EMAS and ISO 14001:2004 will be as widespread as the ISO 9001 standard" was true was answered without clear consensus: A slight majority $(55.9 \%)$ of the respondents answered with "No" and $44.1 \%$ with "Yes". This result is very encouraging in the context of only little interest in environmental management issues within the sector. Nearly half of the respondents were confident that certified environmental management has a good future in the construction industry.

\section{Discussion}

It should be noted that the proportion of certified companies in the sample is significantly higher than the ratio of certified companies in the entire German construction sector. This can be explained by the fact that companies with a certified EMS are more likely to respond to invitations to participate in such surveys. Many of the firms contacted which have not yet adopted an EMS were less interested in the topic and thus in answering the question- naire. Furthermore, the correlation between the companies' size category and the presence of a certified EMS was confirmed. The share of large-scale enterprises in the sample was $32.6 \%$. However, the large-scale enterprises make up a share of just $2.2 \%$ of the entire German construction industry. The certified companies are thus disproportionately overrepresented in the sample. It can be expected that the implementation rate of elements of environmental management in the basic population of construction companies is lower.

According to the results of the survey, there is a relatively low interest in EMS within the non-certified companies surveyed. The majority of the participants was convinced that EMS according to ISO 14001:2004 or EMAS are not suitable for the construction sector or had no opinion about certified EMS in their field of business. This may be due to a general lack of knowledge concerning elements of EMS in construction firms. This finding is confirmed by the investigation of the barriers to implementing EMS in certified companies. Lack of knowledge, a missing scientific basis and the absence of qualified consultants are the major barriers for implementing an EMS. However, the non-certified companies expect great effort involved in introducing an EMS in terms of money, human resources and documentation needed. Thus there is a need for more information within the sector both as to the implementation process itself and on already available guidelines and manuals for implementing elements of environmental management in construction firms. A big knowledge gap can also be determined by taking a look at the assessed benefits of implementing EMS: the motivational factor of "improvement of safety and health protection" is the most important driver. But actually EMS is designed to continuously improve environmental protection. The improvement of safety and health protection is taken into account by introducing an Occupational Health and Safety System (OHSAS). The respondents expected a great benefit in improving safety and health protection. Integrating environmental protection in management systems can, admittedly, help to improve safety and health at work. But of course this is not the core function of an EMS. The hypothesis of QMS paving the way for EMS was confirmed by the large majority (77.7\%) of the certified responding companies. As a result, the introduction of Integrated Management Systems (IMS) should be considered to further promote the improvement of environmental aspects in the construction sector. IMS include quality management, environmental management and health and safety issues. By introducing IMS, synergies can be utilized more effectively and thereby money and employee effort can be saved.

Green aspects continue to receive only very little attention within the procurement process of German contractors. Only a few companies have guidance for environmentally sound procurement. This is because of the requirements of the contractors' clients. Green aspects are used only rarely in the procurement process of public and 
private clients. Hence the incentives for "greening" the construction projects are lacking. Only 4 of the certified respondents stated that they had advantages in contract awards due to their implemented EMS.

A widespread implementation of EMS in a mediumterm time-frame of the next $5-10$ years is seen by nearly half of the respondents. Thus it seems as if EMS are still at an early phase of development in the German construction sector.

\section{Conclusions and recommendations}

Since the global community committed itself to the mission statement of sustainable and environmentally sound development at the United Nations Conference on Environment and Development in Rio de Janeiro in 1992, environmental protection has become a fundamental objective of our society. Environmental awareness is undoubtedly growing in many economic sectors. Although there have been many studies in Germany about sustainability in the construction sector, EMS remain not extensively implemented.

The purpose of this research article was to study the current situation of ecological sustainable corporate business management in German construction companies. Therefore, the state of implementation of elements of environmental management systems in German construction firms was investigated and the barriers and chances for environmental management were studied. Account has been taken of the fact that the German construction sector is characterized by SMEs. Thus it has been considered whether SMEs face different barriers and motivational factors for an EMS-implementation than large firms. On this basis, strategic approaches have been considered to foster EMS in the construction sector. On the basis of the survey's results, the following strategic recommendations can be made to overcome the major barriers identified:

1) The presence of EMS in construction companies has to become a competition factor. This can be achieved by the sector's clients if they apply environmental requirements in their procurement procedures. As these requirements have to be fulfilled by the suppliers and subcontractors as well, the contractors have to develop processes for ecologically sustainable procurement.

2) The SMEs would be particularly motivated to implement EMS if health and safety, productivity and quality issues could thereby be improved. There are synergies between QMS, EMS and health and safety management. The implementation of IMS should thus be encouraged by consultants and decisionmakers.

3) Practical guidelines for best practice in environmental management within the sector are already available, e.g. the "Reference Document on Best Environmental Management Practice in the Building and Construction Sector" (Joint Research Center, Institute for Prospective Technological Studies Sustain- able Production and Consumption Unit 2012). Such guidelines have to be widely communicated. This could be done, e.g. through campaigns of the main association of the German construction industry.

4) The lack of confidence and knowledge in the certification schemes has to be counteracted by up-todate information on the suitability and the benefits of certified EMS. This study has shown that certified companies benefited from EMS. This result could be used to further promote certified EMS in the construction sector.

Green public procurement (GPP) can be an effective way to transfer our recommendation (1) into practice (Varnäs et al. 2009; Uttam et al. 2012; Osebold, Schmidt 2013; Schmidt, Osebold 2013; Bratt et al. 2013). GPP is more than the purchasing of goods and services - it is a policy instrument by means of which green thinking and innovation can be driven. Public awarding authorities serve as a role model in this area and can help to point private organizations in the right direction. However, the contracting authorities have to conform to strict organized awarding procedures. There are various possibilities to apply environmental strategies in the public procurement procedure. According to the results obtained, the use of a selection criterion "Certified EMS" must be viewed as critical. As the level of certified EMS adoption turns out to be very low, the selection criterion would have a restrictive effect on competition. Such a criterion would become more applicable as soon as certified EMS become widely established in the construction sector. Thus the awarding authorities have to consider other possibilities in other aspects of their tenders such as e.g. the bill of quantities, technical specifications, contract performance clauses or award criteria. Several major public awarding authorities in Germany already impose environmental requirements in their procurement process in the stage of tender evaluation (Schmidt, Osebold 2013). It can be recommended that the clients increase the application of environmental requirements in their procurements to foster green thinking in the construction industry. Construction companies should therefore start introducing elements of environmental management. A proactive approach will allow the construction firms to remain highly competitive in the future. A survey will be conducted by the authors of this paper to investigate the state of application of elements of GPP and future changes in this context within public clients' organizations in Germany.

In order to address the matters covered in our recommendation 2 the implementation efforts of EMS have to be studied in more detail. According to early German publications in this field (e. g. Rieger 1999; Follmann 1999) the efforts in terms of costs and human resources for the processes of introduction and implementation are very reasonable. By introducing an IMS, the companies can achieve synergetic effects and hence save efforts. As a majority of the companies have already implemented a QMS, the effort for implementing EMS is much lower 
than most of the firms expect. Therefore, there are many benefits leading to economic advantages. On a strategic level EMS can lead to an improvement in competitiveness (Testa et al. 2011). Additionally corporate image can be improved. The companies have to consider strategically whether they want to counteract competition that is based purely on the price and focus on qualitative aspects such as an environmentally sound project processing. As proposed in our recommendation 3, guidelines may be of assistance in this respect. To further promote certified EMS in the construction industry, it is necessary to counteract the lack of confidence and knowledge in the certification schemes (recommendation 4). This could be reached by agreements between provincial governments and the bodies representing the economy such as the "Environmental Pact" in the German federal state Saarland. The basis of this agreement is a clear commitment of the participants to sustainability: the participating companies voluntarily exceed legal requirements for environmental protection and take further measures such as the establishment of EMS. The provincial government supports these measures through financial support, organizational measures and the simplification of environmental regulations for the participants (Umweltpakt Saar 2012). The "Environmental Pact" is a practical way to promote EMS in the construction sector. This is shown by the high EMAS-certification density in the federal state Saarland: 13 of the 18 EMAS-certified construction companies in Germany are located there (Deutscher Industrie- und Handelskammertag 2013).

As there are no geographical boundaries for global environmental aspects such as $\mathrm{CO}_{2}$-emissions, the implementation of environmental management elements in construction must be dealt with in a global manner. A comparison of the major barriers and benefits expected and experienced for EMS-implementation in the different national construction sectors could help to develop approaches for global sustainability standards.

\section{Acknowledgements}

We would like to thank the participating companies for taking part in the survey. We also acknowledge the two anonymous reviewers and the editor for the fluent processing and their valuable comments on earlier versions of this paper.

\section{References}

Abdullah, A. M. 2005. The extent of environmental management system implementation in the UK construction industry, in Conference on Sustainable Building South East Asia, 11-13 April 2005, Kuala Lumpur, Malaysia. 10 p.

Bentlage, J.; Rieger, H. 1998. Aktuelle Entwicklungen zur Erweiterung des Anwendungsbereiches der EG-Öko-AuditVerordnung, in Doktoranden-Netzwerk Öko-Audit e. v. (Ed.). Umweltmanagementsysteme zwischen Anspruch und Wirklichkeit. Eine interdisziplinäre Auseinandersetzung mit der EG-Öko-Audit-Verordnung und der DIN EN ISO 14001:2004 (2004). Berlin/Heidelberg: Springer, 221-238 (in German).
Blum, A. (Ed.). 1997. Umweltmanagementsysteme und Umweltaudit im Bauwesen. Konzeptionelle Grundlagen und praktische Beispiele. Stuttgart: Fraunhofer-IRB-Verl. 176 s. (in German).

Bratt, C.; Hallstedt, S.; Robèrt, K.-H.; Broman, G.; Oldmark, J. 2013. Assessment of criteria development for public procurement from a strategic sustainability perspective, Journal of Cleaner Production 52: 309-316. http://dx.doi.org/10.1016/j.jclepro.2013.02.007

Bühl, A. 2012. SPSS 20, 13., aktualisierte Auflage. München: Pearson. 142 s. (in German).

Chen, Z.; Li, H. 2006. Environmental management in construction: A quantitative approach. London, New York: Taylor \& Francis. 212 p.

Commission of the European Communities. 2003. Commission Recommendation of 6 May 2003 concerning the definition of micro, small and medium-sized enterprises, Office Journal of the European Union, 20.5.2003.

Deutscher Industrie- und Handelskammertag. 2013. EmasRegister [online], [cited 17 June 2013]. Available from Internet: http://www.emas-register.de/

Environmental Audit Act of 16 August 2002, Federal Law Gazette, Volume 2002, Part I No. 64, published in Bonn on 10 September 2002. 17 p.

European Commission. 2008. EMAS and ISO/EN ISO 14001:2004 (2004): differences and complementaries [online], [cited 26 November 2013]. Available from Internet: http://ec.europa.eu/environment/emas/pdf/factsheet/ fs_iso_en.pdf

European Parliament. 2004. Directive 2004/18/EC of the European Parliament and of the Council of 31 March 2004, Official Journal of the European Union, 2004.

Follmann, F.-J. 1999. Integration des Umwelt- und Arbeitsschutzes in bauindustrielle Managementsysteme: dissertation. Wuppertal: DVP-Verl. (in German).

Gerstkamp, M. 2000. Ein Beitrag zum Umweltmanagement in der Bauunternehmung unter Berücksichtigung der neuen Gesetze und Normen: dissertation. Aachen: Verl. Mainz. (in German).

Girmscheid, G.; Selberherr, J. 2012. Nachhaltige Unternehmensführung - Herausforderung an Planer und Unternehmen. Sustainable Business Management - Challenge for designers and construction companies, Bauingenieur 87(9): 402-409 (in German).

Große, H. 2000. Umweltmanagement in der Bauwirtschaft. Methodik und Arbeitshilfen. Renningen: Expert-Verl. 105 s. (in German).

Hauser, S. 1979. Wahrscheinlichkeitstheorie und schliessende Statistik, Grundriss des Rechts und der Wirtschaft Band 105: Abt. 3, Wirtschaftswissenschaften. Kohlhammer, 1979 (in German).

Hiete, M.; Kuehlen, A.; Schultmann, F. 2011. An approach for an Eco-Management and Audit Scheme (EMAS) for the Construction Sector, in SB11 Helsinki World Sustainable Building Conference, 18-21 October 2011, Helsinki, Finland. $10 \mathrm{p}$.

ISO 14001:2004 Environmental management systems Requirements with guidance for use. International Standards Organization, Geneva, 2004. 23 p.

ISO 9000:2008 Quality management systems- Requirements. International Standards Organization, Geneva, 2009. 91 p.

Jancke, F. 2012. Nachhaltigkeit im Beschaffungsmanagement der Bauindustrie: dissertation. Berlin: DVP-Verl. (in German).

Joint Research Center, Institute for Prospective Technological Studies Sustainable Production and Consumption Unit. 2012. Reference document on best environmental management practice in the building and construction sector. Final Report, September 2012. 56 p. 
NACE Rev. 2. Statistical Classification of Economic Activities in the European Community. Rev. 2, European Communities, 2008. $22 \mathrm{p}$.

Ofori, G. 1992. The environment: the fourth construction project objective?, Construction Management and Economics 10(5): 369-395. http://dx.doi.org/10.1080/01446199200000037

Ofori, G.; Gang, G.; Briffett, C. 2002. Implementing environmental management systems in construction: lessons from quality systems, Building and Environment 37(12): 1397-1407. http://dx.doi.org/10.1016/S0360-1323(01)00115-9

Olshausen, H.-G. 1983. Untersuchung der Belange der Umwelt bei der Durchführung von innerstädtischen Baumaßnahmen und ihr Einfluß auf die Auswahl der Bauverfahren: Abschlußbericht. Stuttgart: IRB Verl. 325 s. (in German).

Osebold, R.; Schmidt, J. 2013. "Grüne Beschaffung" zur ökologischen Verbesserung des Bauprozesses ["Green Procurement" for the ecological improvement of the construction process], Bauingenieur 88(3): 99-104 (in German).

Pape, J.; Rieger, H.; Unger, K.; Müller, M. (Eds). 1998. Umweltmanagementsysteme zwischen Anspruch und Wirklichkeit. Eine interdisziplinäre Auseinandersetzung mit der EGÖko-Audit-Verordnung und der DIN EN ISO 14001:2004 (2004). Berlin Heidelberg: Springer. 342 s. (in German).

Raithel, J. 2008. Quantitative Forschung, 2., durchges. Aufl. Wiesbaden: Verl. Für Sozialwiss. 213 s. (in German).

Rieger, H. 1999. Untersuchung zur Einführung und Umsetzung von Umweltmanagementsystemen in kleinen Bauunternehmen: dissertation. Essen: Verl. Mainz. (in German).

Sakr, D. A.; Sherif, A.; El-Haggar, S. M. 2010. Environmental management systems' awareness: an investigation of top 50 contractors in Egypt, Journal of Cleaner Production 18(3): 210-218. http://dx.doi.org/10.1016/j.jclepro.2009.09.021

Schendera, C. F. G. 2004. Datenmanagement und Datenanalyse mit dem SAS-System, 1. Aufl. München: Oldenbourg. 876 s. (in German).

Schmidt, J.-S.; Osebold, R. 2013. “Greener” procurement of construction works for contracting authorities, in G. Hauser, T. Lützkendorf, N. Eßig (Eds). sb13 munich Implementing Sustainability - Barriers and Chances. Stuttgart: Fraunhofer-IRB-Verlag, 1266-1274.

Šelih, J. 2007. Environmental management systems and construction SMES: a case study for Slovenia, Journal of Civil Engineering and Management 13(3): 217-226.
Shen, L. Y.; Tam, V. W. Y. 2002. Implementation of environmental management in the Hong Kong construction industry, International Journal of Project Management 20(7): 535-543. http://dx.doi.org/10.1016/S0263-7863(01)00054-0

Srdić, A.; Šelih, J. 2011. Integrated quality and sustainability assessment in construction: a conceptual model, Technological and Economic Development of Economy 17(4): $611-626$. http://dx.doi.org/10.3846/20294913.2011.603177

Statistisches Bundesamt. 2013. Produzierendes Gewerbe, Beschäftigung, Umsatz und Investitionen der Unternehmen im Baugewerbe 2011. Wiesbaden, June 2013. 248 s. (in German).

Tan, A. T. K.; Ofori, G.; Briffett, C. 1999. ISO 14000: Its relevance to the construction industry of Singapore and its potential as the next industry milestone, Construction Management and Economics 17(4): 449-461. http://dx.doi.org/10.1080/014461999371376

Testa, F.; Iraldo, F.; Frey, M. 2011. The effect of environmental regulation on firms' competitive performance: the case of the building \& construction sector in some EU regions, Journal of Environmental Management 92(9): 2136-2144. http://dx.doi.org/10.1016/j.jenvman.2011.03.039

Turk, A. M. 2009. The benefits associated with ISO 14001 certification for construction firms: Turkish case, Journal of Cleaner Production 17(5): 559-569. http://dx.doi.org/10.1016/j.jclepro.2008.11.001

TVgG-NRW. 2012. Tariftreue- und Vergabegesetz NordrheinWestfalen, "Act for Adherence to Rates and Public Procurement of North Rhine-Westphalia". Landtag Nordrhein-Westfalen, 1. Fassung (in German).

Umweltpakt Saar. 2012. Umweltpakt Saar 2012-2016 [online], [cited 17 December 2013]. Available from Internet: http://www.saarland.de/dokumente/thema umweltpakt/ Brosch_Umweltpakt2012_Druckversion.pdf

Uttam, K.; Faith-Ell, C.; Balfors, B. 2012. EIA and green procurement: Opportunities for strengthening their coordination, Environmental Impact Assessment Review 33(1): 73-79. http://dx.doi.org/10.1016/j.eiar.2011.10.007

Varnäs, A.; Balfors, B.; Faith-Ell, C. 2009. Environmental consideration in procurement of construction contracts: current practice, problems and opportunities in green procurement in the Swedish construction industry, Journal of Cleaner Production 17(13): 1214-1222. http://dx.doi.org/10.1016/j.jclepro.2009.04.001

Zeng, S. X.; Tian, P.; Tam, C.; Tam, V. W. Y. 2004. Implementation of environmental management in the construction industry of China, Architectural Science Review 47(1): 19-26.

Jan-Simon SCHMIDT. Was research Associate at the Chair of Construction Business and Project Management at the RWTH Aachen University from 2011 to 2016. He holds a doctors degree (Doktor-Ingenieur) in civil engineering of the RWTH Aachen University. From 2011-2016 he was working on a research project about environmental management in a large-size infrastructure project in Germany. His research interests concern Green Public Procurement (GPP) in the construction sector, the "greening" of the supply chain of large public contracting authorities and strategic aspects of environmental management systems in construction companies. Since 2016 Dr. Jan-Simon Schmidt is managing director of an engineering consultans firm in Stuttgart, Germany.

Rainard OSEBOLD. University Professor at the Chair of Construction Business and Project Management at the RWTH Aachen University since 2003. His area of specialty is the development and implementation of innovative strategies as well as organization and personnel development in the highly-competitive construction business. 